\title{
FACTORS ASSOCIATED WITH MATERNAL KNOWLEDGE ABOUT EYE HEALTH IN PREGNANCY AT GUNUNGPATI COMMUNITY HEALTH CENTER, SEMARANG
}

\author{
Trilaksana Nugroho'), Hari Peni Julianti²) \\ 1)Department of Ophthalmology, Faculty of Medicine, \\ Universitas Diponegoro, Semarang \\ 2)Department of Public Health and Preventive Medicine, \\ Faculty of Medicine, Universitas Diponegoro
}

\begin{abstract}
Background: Pregnancy causes hemodynamic changes and extracellular matrix structures, collagen sclera associated with refractive status. The addition of refractive status to high retention rates in myopia may result in permanent viscosity and blindness. Pregnant women should be aware of this condition. This study aimed to determine the factors associated with maternal knowledge about eye health in pregnancy among pregnant women at Gunungpati community health center, Semarang.

Subjects and Method: This was a cross-sectional design conducted at Gunungpati community health center, Semarang, Central Java. A sample of 53 pregnant women was selected for this study by simple random sampling. The dependent variable was maternal knowledge about eye health in pregnancy. The independent variables were gestational age, maternal education, eye disorder, refraction status, history of eye examination, and informational exposure. The data were collected by questionnaire. Percent of good knowledge by the independent variable status (i.e. "exposed" and "non-exposed" groups) was compared to result in Prevalence Ratio, which was then tested by chi square.

Results: $69.8 \%$ pregnant women had poor knowledge, $30.2 \%$ had good knowledge about eye health in pregnancy. None of the pregnant women received information of eye health in pregnancy from health personnel. Maternal knowledge about eye health in pregnancy was higher among pregnant women with high education $(\mathrm{PR}=2.31 ; 95 \% \mathrm{CI}=1.60$ to $3.35 ; \mathrm{p}<0.001)$, presence of refraction status $(\mathrm{PR}=8.12 ; 95 \% \mathrm{CI}=6.42$ to $10.28 ; \mathrm{p}=0.007)$, younger gestational age $(P R=0.43 ; 95 \% \mathrm{CI}=0.11$ to $1.68 ; \mathrm{p}=0.215)$, absence of eye disorder $(\mathrm{PR}=0.86 ; 95 \% \mathrm{CI}=0.07$ to $10.12 ; \mathrm{p}=0.903)$, and history of eye examination $(\mathrm{PR}=1.17 ; 95 \% \mathrm{CI}=0.10$ to $13.87 ; \mathrm{p}=0.903)$.

Conclusion: Maternal knowledge about eye examination in pregnancy is associated with education, refraction status, gestational age, eye disorder, and eye examination.
\end{abstract}

Keywords: eye examination, knowledge, refraction status, eye disorder, pregnant mother

\section{Correspondence:}

Hari Peni Julianti. Department of Public Health and Preventive Medicine, Faculty of Medicine, Universitas Diponegoro. 